Educational Research for Social Change (ERSC)

Volume: 6 No. 2, September 2017

pp. $45-59$

ersc.nmmu.ac.za

ISSN: 2221-4070

\title{
Privilege, Poverty, and Pedagogy: Reflections on the Introduction of a Service-Learning Component into a Postgraduate Political Studies Course
}

Sally Matthews

Department of Political and International Studies, Rhodes University

s.matthews@ru.ac.za

\section{Abstract}

This paper reflects on the experience of integrating a service-learning component into a postgraduate course in political studies. The course in question aims to get students to reflect on the ways in which poverty and privilege are tied up with each other, and on whether and how the relatively privileged can be involved in helpful ways in struggles against oppression. The service-learning component involved spending a week volunteering with a rural community-based organisation. Students were required to relate their volunteering experience to the course content. The paper reflects on the implications of the course's failure to live up to many criteria for quality service-learning, arguing that despite its failings, the service-learning experience significantly enhanced the learning of the students and also my own learning as an educator. I show that the nature of this learning calls into question some possible assumptions about how service-learning ought to be done. The paper contributes to ongoing discussions about the ways in which service-learning can assist in the achievement of social justice-related goals.

Keywords: service-learning, social justice, privilege, community engagement

Copyright: (C) 2017 Matthews

This is an open access article distributed under the terms of the Creative Commons Attribution Non-Commercial License, which permits unrestricted non-commercial use, distribution, and reproduction in any medium, provided the original author and source are credited.

\section{Please reference as:}

Matthews, S. (2017). Privilege, Poverty, and Pedagogy: Reflections on the Introduction of a ServiceLearning Component into a Postgraduate Political Studies Course. Educational Research for Social Change, 5(2), 45-59. http://dx.doi.org/10.17159/2221-4070/2017/v6i2a4 
"Service-learning is not safe. It is anything but safe."

-Dan Butin (2010, p. 18)

\section{Introduction}

A few years back I launched a postgraduate course called Poverty and Privilege, as part of a postgraduate honours programme in political and international studies. The course was intended to acquaint students with a broad range of debates about the role of privileged actors in struggles against poverty. Key themes in the course were inequality, charity, solidarity, white antiracism, male feminism, and the role of nongovernmental organisations in popular struggles. After teaching the course for the first time, I felt that it had been a valuable learning experience, but that students would come to reflect more deeply and in a more nuanced way on the issues concerned if a service-learning component were added to the course. Consequently, the second time I taught the course, I adapted it so that a servicelearning component could be included. In this paper, I reflect on my experience of introducing servicelearning into the course. The paper explores some of the shortcomings, but also some of the surprising benefits of the introduction of this particular service-learning initiative. The goal of the paper is to add to discussion about the possibility of using service-learning to achieve social justice-related goals. As I show below, there is some debate about the possibility of using service-learning to promote the achievement of justice, and my discussion of service-learning suggests some potential challenges to using it in this way.

Before proceeding, it is necessary to make a few brief comments about methodology. This article is not the conventional product of a research project but is, rather, a reflective piece that looks back on a teaching experience. When I set out to introduce service-learning into the course concerned, I did not intend to write about my experience. However, the experience was so noteworthy and, honestly, so difficult, that I was later drawn to putting together this paper. In putting it together, I have drawn principally on my own reflections but also on the reflective pieces submitted by some students who took part in the course. All students who are quoted below have given their written permission for their quotes to be used, and have been given the opportunity to comment on this piece.

\section{Defining Service-Learning}

Service-learning is a much debated but popular term used to describe various kinds of out-ofclassroom experiences that form part of academic programmes at learning institutions. Increased interest in service-learning is part of a general increased interest in various forms of community engagement. Community engagement refers to a range of activities through which the university in some way engages with the surrounding community, usually with the intention to respond to the needs of the community. Service-learning is a specific form of community engagement that is integrated into a particular course or programme, and which combines the achievement of educational goals with the meeting of some or other community need.

It is not easy to clearly define service-learning-Eyler and Giles (1999) noted that over a hundred different definitions of the term exist. A very simple definition is provided by Stanton, Giles, and Cruz (1999), who described it as "the accomplishment of tasks that meet genuine human needs in combination with conscious educational growth." Bringle and Hatcher's (1995) more comprehensive definition described it as, 
a credit-bearing educational experience where students (a) participate in an organised service activity that meets identified community needs and (b) reflect on the activity so as to gain further understanding of course content, broaden their appreciation of the discipline and enhance a sense of civic responsibility. (p. 112)

Finally, a very neat definition is provided by Butin (2010, p. xiv) who defined it as "the linkage of academic work with community-based engagement within a framework of respect, reciprocity, relevance and reflection." What all three of these definitions emphasise is that service-learning has two key components: it must involve some kind of learning experience, and it must involve providing a service of some kind to a community of people outside of the classroom.

The above definitions also point to the important role of reflection in service-learning-servicelearning not only requires students to do some kind of service as part of, or alongside, their academic learning process, but also requires students to reflect on the service component, typically under the guidance of the course coordinator. Thus Eyler and Giles (1999, p. 4) commented that "the hyphen in the phrase [service-learning] symbolises the central role of reflection in the process of learning through community service."

\section{Service-Learning and Social Justice}

To be orientated towards social justice means, generally speaking, to be committed to working towards a more egalitarian society. In their discussions of the concept of social justice, Barry (2005) and Miller (1999) described the term as suggesting a fairer, more equal distribution of income and as generally being associated with egalitarian, left-leaning struggles. To be preoccupied with social justice is therefore to be preoccupied with being responsive to poverty, inequality, and oppression. Servicelearning typically involves something of an orientation towards the achievement of social justiceafter all, it aims to meet some kind of identified community need and is premised upon the assumption that universities should be responsive to the communities in which they are rooted. However, the content of the course concerned need not be explicitly related to social justice. For example, students studying fisheries management might deepen their understanding of management techniques by assisting a fishing community. Or pharmacy students might entrench their knowledge of a particular drug treatment regime by drawing up pamphlets for distribution at a local clinic. In these cases, the course concerned has nothing to do with questions of justice at all, although the decision to introduce service-learning into a course may be related to justice because it is premised upon a desire to attend to community needs. However, service-learning is sometimes integrated into courses where the very content of the course itself is aimed at getting students to reflect on questions related to social justice and the service-learning component is intended to improve their reflections on this very issue. This was the case with my course and so before introducing the particular course under discussion in this paper, it is useful to look at the question of whether, and how, service-learning can be used in such courses.

One way in which service-learning is sometimes explicitly related to concerns around social justice is when it is introduced as part of courses in ethics. Here, the service-learning is supposed to provide students with an out-of-classroom experience that illustrates the ethical questions being discussed in class. In such cases, the introduction of service-learning is intended to deepen students' understanding of social justice and better enable students to enact positive social change. As Seider and Taylor (2011, p. 201) noted, humanities programmes are often very classroom based, with few opportunities for internships or other out-of-classroom activities; humanities, they said, is "assumed to be the territory of abstraction and reflection, but not action." Similarly, Scholz $(2000$, p. 185) noted that for many students who study ethics courses at universities, their examination of ethical questions "is merely a mental exercise that does not affect their daily lives." Scholars like Seider and Taylor and Scholz have 
attempted to introduce service-learning in order to make a connection between classroom discussions about topics related to social justice and actual real-life situations. In this way, students may come to better understand the importance of the theories in question and to be better able to apply them once they leave the classroom.

In the case of the courses discussed by Seider and Taylor (2011) and by Scholz (2000), the service placements are simply aimed at exposing students to the challenges faced by marginalised communities. So, for example, in the Pulse Programme discussed by Seider and Taylor (2011), students volunteered at underprivileged high schools or assisted homeless people and, in Scholz's ethics course, they spent time at a mission that engaged in typical charity-related work. In contrast, a different approach to linking service-learning to concerns about social justice resists this charity orientation in favour of an approach that is less concerned with providing students with exposure to the less fortunate through charity work, and more concerned with encouraging students to work to change the conditions that result in poverty and inequality. For example, Artz (2001) and Mitchell (2007) both talked about critical service-learning, which they contrasted with more charity-orientated approaches to service-learning. Instead of encouraging students to ask "How can I help the poor?", a critical service-learning approach encourages them to ask why people have become poor or marginalised (Mitchell, 2007, p. 102; see also Osman \& Petersen, 2013). Similarly, Mahlomaholo and Matobako (2006) distinguished between approaches to service-learning that engage the community at the level of charity or at the level of a project, and those that constitute genuine engagement, which is driven by the interests of the community rather than those of the university. The latter form of engagement, they argued, must be explicitly tied to an understanding of knowledge that critiques oppression and aims at emancipation.

One of the most helpful aspects of service-learning in relation to any course on social justice is its ability to encourage students to think critically about the very possibility of properly understanding social justice. Students, who might otherwise develop quite fixed positions on how to address social justice, are encouraged to develop far more nuanced and complex positions as a result of service-learning because it forces them to confront situations and experiences that challenge rather than confirm their existing views. Butin $(2007$, p. 181$)$ noted that the "sheer complexity of social reality-when carefully and systematically examined and reflected upon-yields opportunities for the realisation that justice (or the lack thereof) is contingent upon our engagement with the world." Students come to recognise their own positionality, to become more aware of the difficulty of properly understanding the world (Rhoads, 1997). We could say that service-learning is valuable not only because it helps illustrate ethical arguments or encourages students to challenge social injustices, but also because it unsettles our students' too-easy assumptions about social justice. Through such unsettling, students come to approach discussions about justice "from a position of doubt rather than certainty" (Butin, 2010, pp. 13-14). This kind of position opens them up to new learning.

In summary, we could say that service-learning is considered to facilitate the achievement of social justice and the promotion of positive social change in a range of ways. Firstly, some scholars believe that understanding of social justice issues is improved when students are exposed to real-life situations rather than simply reflecting on social justice. Secondly, advocates of critical service-learning believe that it can help students better understand oppression and enable them to use knowledge in emancipatory ways. And, thirdly, service-learning is thought to help students become more aware of the complexities related to the achievement of social justice.

\section{Teaching Poverty and Privilege with a Service-Learning Component}

Literature relating service-learning and social justice is of great relevance to this paper because the course I teach aims quite explicitly at getting students to think about questions of social justice. The 
course encourages students to reflect on inequality and, particularly, to think about the ways in which the relatively privileged can-and cannot-appropriately involve themselves in the struggles of the oppressed. We begin by looking very generally at concepts such as inequality, poverty, and privilege and then move on to look at various ways in which the privileged can respond to poverty and oppression-charity, solidarity, activism, NGO work, and so on. I quite explicitly foreground the fact that students in the course are likely to occupy a privileged position in society (even if they don't come from a privileged background) and that they need to reflect on what role they might be able to play in bringing about a more just and equitable order. Students are invited to reflect very critically on the ways in which relatively privileged people have intervened in poor people's struggles, sometimes in very damaging ways. The course is thus quite self-consciously aimed at contributing to struggles for social justice and, ultimately, about trying to encourage students to think of ways in which they can contribute to positive social change.

The course, which is offered to postgraduate students in the Department of Political and International Studies at Rhodes University, is a semester course that makes up one fifth of the credits for an honours degree. In other similar courses in the department, students are required to attend weekly $2 \frac{1}{2}$ hour seminars for which they have prepared by reading prescribed texts. During the seminars, they are expected to participate actively in the discussion, although the discussion is often dominated by the lecturer giving the course. Students are often required to make short presentations on a particular topic and are occasionally also asked to participate in other ways during the class-for example, in small group discussions, debates, or even mock United Nations sessions or other creative engagements. Such courses are usually evaluated by means of several pieces of writing-typically a long essay and an exam or a collection of shorter pieces of writing and one longer essay (replacing the exam). When I had presented the course previously, I presented it in much the same way as described above. In short, the students read a lot of texts, discussed them, and wrote about them.

When students write essays in political studies, they are required to put together plausible, wellstructured, and convincing arguments in favour of a particular position. Consequently, two students in the class might both write excellent essays while defending very different positions. While this approach has its benefits, it does tend to allow students to quite easily dismiss positions they intuitively dislike, and focus instead on building arguments that fit comfortably into their existing worldview. They then seek out literature that defends the position they already hold (or, sometimes, the position they think the lecturer would like them to embrace), and then write an essay defending that position. When I had taught students the Poverty and Privilege course previously, I noted that many students adopted a very critical stance towards nongovernmental organisations, arguing that such organisations did not reflect the actual interests or preferences of the communities they supposedly served, but rather imposed problematic agendas that originated with their funders rather than the communities concerned. My students felt that popular movements could more authentically represent people. While this view has many merits (and indeed my own teaching had contributed to students developing this view), my engagements with NGOs suggested to me that the situation on the ground is far more complicated-not all NGOs impose foreign agendas, and not all communities are well represented by effective and democratically organised popular movements. Furthermore, the distinction between "the privileged" and "the oppressed" is far more tenuous than some students imagine. While I did not think my students' views were incorrect, I did think they needed nuancing, and thought that an outof-classroom component could help in this regard. And so, with these concerns in mind, I set about introducing a service-learning component into an existing course.

While preparing to teach the course for a second time, I thought of an acquaintance who had contacted me previously, asking me to assist him in finding volunteers to spend some time working with a community-based organisation he had set up in his home village. It occurred to me that it might be interesting to send students to volunteer in this organisation as part of the Poverty and Privilege course 
when next I taught it. After taking into account various considerations-funding, convenience for both the students and the community organisation, and so forth -1 proposed that the course include a service-learning component during which students would spend around 10 days volunteering with the organisation. The volunteering period would fall into the midsemester break, and so it would happen in the middle of the course. The arrangement I had with the organisation concerned was that what the students did there would depend upon the preferences of the organisation, and that we would pay the organisation for community-based accommodation and bring along our own food.

Postgraduate students in our department (who usually number between 30 and 45 students in total) are required to sign up for five of the approximately 15 courses on offer each year. This course was one of the 15 options available that year, and was the only one with a service-learning component. Twenty students signed up for the course. Each of the 15 courses on offer usually attracts only around five to 15 students so the large sign-up suggested that the students liked the idea of doing servicelearning.

Before the students went, we discussed the idea of keeping reflective diaries while they were there. While these were not to be submitted, the students were required to use these diaries to write a 2000word reflective piece (to be submitted about a month after their return) in which they were asked to relate their experiences in the field to the course content. This reflective piece would count $20 \%$ of their final mark for the course, making it the second biggest component of the assessment (the largest being the final essay, worth $40 \%$ ).

And so, with this plan in place, we headed out on my first attempt to introduce service-learning into a university course. I hoped this course would set a precedent and that service-learning could become a feature of my own teaching, and even thought that colleagues in my department, none of whom had previously used service-learning, might in future consider it.

\section{Confronting Failure}

Unfortunately, things do not always go according to plan. The service-learning did not pan out quite as expected. Looking back on the experience, I can see that it did not meet the requirements of what Eyler and Giles (1999, pp. 190-191) called a "high quality" service-learning placement. Such a placement should meet the following criteria:

- Students do meaningful work.

- Students have important responsibilities.

- Students have varied and challenging tasks.

- Students work directly with community partners.

- Students receive support and feedback from agency staff.

- The service continues over a sustained period.

My students' service-learning experience met few of these requirements. The only criteria that were met were that the students did work directly with the community partner, and did receive some support and guidance from some of the organisation's staff. I had left it up to the organisation to decide how best they would like to use the students and, while various possibilities were discussed in the buildup to the volunteering period, the students ended up spending most of their time with the organisation doing quite menial, rather than varied and challenging tasks. They certainly did not have any important responsibilities but, rather, worked alongside community members to cut grass and 
poles that the organisation planned to use in building a thatched office building. It is difficult to see any way in which the students' university-related skills were used during the period. Other than doing this menial work, much of their time was spent hanging around, socialising with each other and community members, and just going about the day-to-day tasks of food preparation and getting from one place to another in a rural setting. These day-to-day tasks sometimes took very long because the students were housed in three groups quite far from each other and because water and electricity were not always available at all three sites. Furthermore, the placement only ended up lasting just over a week, which hardly qualifies as a sustained period.

It seems then that my first venture into service-learning was a textbook case of service-learning failure. However, in the course evaluations I very nervously conducted at the end of the course, I was somewhat surprised to find that only one student indicated that he or she felt that the service-learning component had not contributed to his or her learning. Thus, in general, the group felt that they had learnt something despite the fact that the experience did not meet the requirements of a high quality placement described above. What was it that they learnt and what can this tell us about using servicelearning in a course like this? The rest of the article explores some of the ways in which this servicelearning placement did result in learning, and reflects on what this might mean when thinking about introducing similar kinds of learning experiences.

\section{Service-Learning and the Building of a Learning Community}

Service-learning is supposed to meet educational goals - it is service-learning after all. In the case of the experience discussed above, it is difficult to see in what ways cutting grass and trees helped students learn something. However, it became clear to me later that the time spent together in this way helped build a learning community among what was previously a group of individuals. The week spent with the community organisation was very successful at building friendships between the students and at strengthening the cohesion of the group. While the students all knew each other at least to some extent, they got to know each other in a completely different way during the servicelearning trip. Because the students had to spend a week eating, sleeping, and working together, they had far more opportunities for social contact than they would have had had there been no servicelearning component, or if the service-learning component had entailed an hour or two in the community each week. I was impressed at how my fairly diverse group of students got along fairly well during the trip, with no significant tensions or conflicts developing between them (at least, to my knowledge). What was also notable was that whereas in a classroom situation, academic ability strongly influences how students come to know and value each other, in this context those who were less academically capable or less confident to speak in class came to be valued for their other skillsfor example, their cooking, their kindness, their cheerfulness, or their ability to take good photos. The difference was very noticeable at the first seminar after the trip, when the students were openly joking with each other before class and two had got together before class to bake muffins, which they brought to share with everyone. New friendships had evidently been formed, and old friendships strengthened.

Several of the students commented on this aspect of the service-learning component in their reflective pieces:

This experience of working together manually with my classmates also created friendship between several individuals who possibly could have never done that in an academic space. It was an opportunity where as students we were able to know each other at a personal level and also try understand each other's characters as we had to work together and stay together for those days. It was also a refreshing experience as I had conversation with other people I thought I could never talk to within the classroom. 
What I appreciated about the field trip was interacting with my classmates outside an academic environment where we are usually arguing discourses and literature. It was [great] to get to know people in a more relaxed environment and getting to get an informed understanding of each individual, playing games and having a good laugh about nothing.

However, some students had opted out of the service-learning component of the course. While I had made it clear to the students at the outset that this component was a compulsory part of the course, closer to the time a few students began to raise all kinds of objections, some to me directly while others were communicated to me indirectly by other students. After some deliberation, I decided to open up an opt-out option where students could replace the service-learning with additional academic writing. I felt that it was not fair to the organisation to bring reluctant volunteers on the trip. In the end, six of the 20 students opted out-four citing academic and personal pressures, and two at the last minute due to illness and death in the family. Two of the students who had cited academic reasons for withdrawing were among the strongest students, academically, and had dominated many of the class discussions. After the service-learning trip, the dynamics in the class changed and the formerly quiet students appeared more confident and willing to engage. We only had a handful of seminars post-trip (in order to keep the number of notional hours in the course from becoming much greater than those of other courses), and so my comments are very tentative, but my sense was that the service-learning experience changed class dynamics by allowing students who were less academically strong, or less confident in the classroom setting, to have an opportunity to excel and build confidence through being required to do a range of tasks about which they felt more confident. Indeed, when evaluating the course, $71 \%$ of the students who completed the evaluation agreed with the statement: "I found that the class dynamics changed after the service-learning trip," supporting my sense that the trip had changed the way the class interacted significantly.

The experience also changed my own relationship with the students. Although I did not stay with them for the entire trip, I spent a few nights there with them and thereby got to know them much better than I would usually get to know students in my classes. I found my perceptions about particular students changed considerably through seeing them in a different context, and through having opportunities to talk to them socially and to get to know more about their lives outside the classroom.

All of the above ostensibly has little to do with learning; however, I think the above changes did impact indirectly on the students' learning. By changing the dynamics in the class, students who had felt quite alienated in class prior to the service-learning trip came to find the classroom space at least somewhat more welcoming-which impacted upon their learning experience as a whole. My own changed and deepened relationship with the students made me more aware of the class dynamics, and more concerned about recognising and validating a broader range of skills rather than being preoccupied only with students' ability to articulate themselves well in academic writing.

These kinds of benefits of service-learning have also been noted by others. For example, Scholz found that service-learning had an "important and unexpected result" (2000, p. 188)-students developed more interest in each other and came to understand their learning as being part of "a common learning endeavour." Her students' comments on the experience are quite similar to those of my students:

[The service-learning] also brought about a sense of unity to the class [that] makes it all the more comfortable to discuss and debate issues in class.

The group project is also beneficial because it gave the students an opportunity to get to know their classmates in a more personal way. This is important in recognising our ethical 
responsibility to others as well, recognising our interdependence and relationships with

others around us, both those we know and those we have never met. (Scholz, 2000, p. 188)

It seems that getting students out of the classroom and engaged in collaborative service-learning activities can help to build a learning community and a less individualistic approach to learning.

\section{"Inappropriate" Work and Service-Learning}

According to my university's online guidelines for service-learning, it should involve "both rigorous academic learning and a closely connected [emphasis added] planned service activity" (Rhodes University, 2016). Service-learning should relate closely to the academic goals of the course concerned and should allow students to use their skills to provide a service to the community and, in so doing, further hone their skills in preparation for their post-university lives. In the case of the course under discussion, the students' volunteering experience could potentially allow them to use their skills to further the interests of the organisation. I had been told that previous groups of student volunteers with the organisation concerned had helped develop written material promoting the organisation and had also been involved in tutoring high school students. I imagined my students might help write newsletters for the organisation or develop proposals for funding or do some other service in which they could use their writing skills and theoretical knowledge to advance the interests of the community, which I imagined, might not have many people with such skills. However, as discussed above, the organisation decided that the best way to use the students at that particular point in time would be to get them to spend their week working alongside community volunteers in the early stages of constructing a building that they planned to use as a kind of headquarters for the organisation, which at the time operated out of a hut in the director's family's yard. As mentioned above, the students spent their week cutting grass and poles and constructing a fence as well as a shelter to store the grass, which would eventually be used for thatching. They worked alongside volunteers from the community doing very basic, unskilled work.

I initially felt quite disappointed that the students had not been able to use and further develop the kinds of abilities they had been learning at the university. However, on reflection I am glad the servicelearning turned out this way. Had students spent more time in the organisation's office preparing written documentation, they would not have got to know community volunteers as well as they did. By working side-by-side with community volunteers, students managed to get a better sense of how the community itself worked as well as to hear about some of the challenges related to running an NGO in that environment. So, even though cutting grass or building a fence ostensibly had absolutely nothing to do with their studies, they developed certain insights into the functioning of the NGO by working alongside community volunteers. Acquiring a better understanding of the functioning of NGOs was precisely the learning outcome I had intended them to acquire during the trip and so the "menial" tasks can be understood to have contributed to their learning.

Lewis (2004) discussed a situation that made me see some other advantages to the activities my students had undertaken during the service-learning component. She talked about a group of environmental studies students who provided a particular community with a guide about how to create a community garden. Doing this allowed them to use what they had already learnt about environmentalism and gave them an opportunity to try to apply this knowledge. However, the community was disappointed with receiving this guide because what they wanted was for the students to actually work alongside them in creating the garden rather than just providing them with a guide. What struck me on reading about this incident was that when students use the abilities they have developed at the university, rather than doing more menial work, they have fewer opportunities to interact with community members as equals, and they potentially reinforce existing hierarchies about who produces knowledge and who provides manual labour. 
Perhaps we need to recognise that it is hard to be sure about how best students can contribute to community projects. Lewis noted that even when students are apparently just doing "charity" work that seems unrelated to their academic learning, their work often helps them develop "structural understandings of service providers that can be translated in social change later in their careers" (2004, p. 107). Similarly, the time my students spent doing menial work alongside community volunteers resulted in conversations with these volunteers that revealed to the students certain ways in which the organisation worked, which would otherwise have remained invisible to them and thus, arguably, did help them understand how NGOs work-and in a deeper way than they would have had they been involved only with the organisation's leaders in drawing up proposals and writing reports.

One of the students' reflections suggested a critique of the idea, expressed by Eyler and Giles (1999, pp. 190-191), that students ought to have "important responsibilities" in an ideal service-learning placement. This student had witnessed some tension between some students and the leader of the organisation and felt that some of the students wanted to do more "important" things and were reluctant to follow the instructions of the NGO. She commented:

Many of us firstly undermined the NGO's decision on the programme, a number of us could not grasp why an organisation would want to use skilled volunteers to cut grass when it can exploit our skills, we believed that we could help the organisation with other "important" things like administrative work. We had assumed that we (the volunteers, being educated) could do administration work more efficiently than the locals.

While this student clearly felt that some students had not valued doing menial work, some of her classmates included comments in their reflections that suggested that at least some students were able to see the value of the more menial tasks they performed. Here are two such comments:

I think that it was important that the class went on the [service-learning trip] at a moment where there was no set agenda because we were then able to experience the tedious work that local based NGOs have to do throughout the year. It is not exciting, life changing or philosophically purposeful work but it is necessary work. I think that often when people go on organised trips to work with an NGO when there is a set agenda there is a limitation to the kind of engagement you can have with the people you are working with and the people around you. Our daily work consisted of cutting grass, which seems an ordinary task but is extremely challenging, for thatching and later involved the cutting down and shaping of trees to create a shelter. This was all part of the foundational moments of working towards building an office building for [the organisation] to operate from. Every day we woke up from our different locations and joined together at the working site with members of the community who volunteer with [the organisation] from the different villages involved with the organisation. There was an important interaction between us and the local people on a daily basis, which enabled a real conversation to occur and added a relational aspect to our daily activities.

Although we were all coming from different backgrounds, a sense of oneness and unity was built as students and the community workers were able to mingle and work together irrespective of language barrier, intellectuality, and class differences. This evoked a feeling of victory and hope for better futures where people from different classes can stand in solidarity in pursuit for a universal goal. I also felt more attached to the reality of the plight of the people as one of the ladies poured out her sufferings to me.

What is interesting to note in the above comments, is the way in which the "inappropriate" work that the students ended up doing, did in fact help them better understand how NGOs work, which was an 
important goal of the service-learning experience. The students' experiences also suggest that if we are too insistent on students doing work that is relevant to their studies, we might reinforce existing hierarchies in which the educated university student is positioned above "ordinary" community members. It is therefore worth acknowledging that seemingly inappropriate work may actually yield quite useful learning.

\section{Identifying and Assessing the Learning in Service-Learning}

What the foregoing discussion also suggests is that we need to think very carefully about exactly what we expect students to learn during service-learning, and exactly how we can assess this learning. We also need to accept that service-learning cannot easily be slotted into an academic programme while leaving the rest of the programme and the whole underlying pedagogy unchanged. As Howard (1998) argued, service-learning is a counter-normative pedagogy-it will not therefore sit comfortably alongside traditional pedagogies and is therefore likely to unsettle the programmes in which it is incorporated.

Butin's (2010) reflections on an antifoundationalist perspective on service-learning are helpful in thinking through the broader implications of the introduction of service-learning. He suggested that one of the key benefits of service-learning is its very open-endedness, insisting that when doing service-learning we ought to avoid being "directed towards some specific and predetermined end goal" (Butin, 2010, p. 13). Service-learning is very good at disrupting our expectations, the things we take for granted, our commonsense assumptions and it is this, Butin suggested, that is its key strength. In his words:

Service-learning frees us from the false notion of controllable teaching of controlled subject matter, from knowledge as static, and from truth as fixed. . . Service-learning is never a transparent activity that accomplishes exactly what $I$, as the instructor, want it to accomplish. There is always a slippage exactly because of the reality that service-learning is an embodied and experiential activity that cannot be contained-as much teaching and learning attempts to be-within the four walls of the classroom and the covers of the textbook. (2010, p. 46)

This does not mean that we should venture into service-learning without carefully planning and reflecting, but it does mean that we ought to welcome rather than resist experiences that are unsettling and which take our students' learning in unexpected directions. The introduction of servicelearning is likely to unsettle our (and our students') ideas of how to learn and of what university education is all about.

One aspect of our teaching that is likely to be challenged by service-learning is assessment because the open-endedness of service-learning raises some serious challenges for assessing student learning. If I am to be open to the possibility that students might learn something unexpected, how do I set out the course's learning outcomes, and how do I decide what learning to assess and how? The South African Council on Higher Education makes it very clear that when we assess service-learning, we must be assessing the educational achievements of students: "Academic credit is for learning, not for service," it says, stressing that students must be given credit "not for the community service they perform but for the quality of learning that takes place" (as cited in Bender, Daniels, Lazarus, Naude, \& Sattar, 2006, p. 32). This is all very well, but the very nature of this kind of experiential learning makes it quite challenging to pinpoint what students have learnt and to assign credits to this learning. 
Kezar (2002) argued that supporters of service-learning might need to challenge entrenched ideas about what it is students are supposed to learn at university, and how such learning is best assessed. She argued that service-learning is very useful in developing certain important abilities, but that these abilities are often difficult to assess. For example, her research suggests that service-learning assists in the development of moral reasoning and tolerance, in developing leadership skills, and in getting students to question stereotypes (Kezar, 2002). None of these abilities is very easy to assess. Indeed, it is often hard to even argue that the development of such abilities is a legitimate outcome of university-level teaching. Are we supposed to be teaching students to question stereotypes? Is the development of moral reasoning something that ought to be an outcome of a university course?

One possible avenue here, at least in the South African context, is to bear in mind the "critical crossfield outcomes" that can (and should) be included in a range of university-level courses (South African Qualifications Authority, 2000, pp. 18-19). Included here, are outcomes as such working well in a team, being able to solve problems in a creative way, being able to organise oneself in a responsible and effective way, and being able to communicate effectively. These kinds of outcomes are sufficiently open-ended as to make them appropriate for a service-learning component-and including consideration of such outcomes allows one to recognise and affirm those students who approach the service-learning with maturity, and who work well with others. So much academic work is very individualistic and, in my discipline at least, very focused on developing the ability to clearly articulate, especially in writing, a range of scholarly ideas. Less emphasis is placed on collaborative learning, effective verbal communication, and open-mindedness, even though these are all, surely, also the kinds of abilities that should be deepened at university.

As mentioned above, the only way in which I assessed the service-learning component was through requiring students to submit a reflective piece on their experience, which was worth $20 \%$ of the course mark. However, I am not convinced that that was an adequate way to assess this component of the course. The reflective piece required students to make links between the readings and their volunteering experience so, as with other assessment tasks, students were once again required to write and to relate to academic texts. Students spend the whole course engaging with readings and so it did not feel that what they were doing was all that different from other written submissions. There were a few students in the course who were not very adept at handling academic texts, but who were cheerful, committed volunteers who treated community members and other students respectfully and responsibly and worked well in a team. The assessment methods I had set up at the beginning of the course could not give any credit for these abilities. When I next teach the course, I would like to find ways to assess students' ability to work in groups, to communicate effectively verbally, and to demonstrate respectfulness and responsibility. Peer assessment might be helpful here, particularly in assessing students' ability to work together in groups. These are legitimate outcomes of a servicelearning experience and so ought to be accorded credit. Furthermore, these kinds of outcomes are not tied to very narrowly defined objectives and so they are compatible with the open-ended approach suggested by Butin (2010) and discussed above.

\section{Conclusion}

When I think back on this service-learning experience, I realise that while I still have some uncertainties about what exactly my students learnt during the experience, I have no doubt that they and I, as an educator, learnt immensely from this experience. The learning was hard and unsettling, but it was certainly learning. Butin (2010) very nicely captured some of the reasons why service-learning is so unsettling for those who introduce it into their teaching. He said that service-learning, 
subverts some of our dearest foundational assumptions of our sense of identity as higher education faculty. We must rethink the belief that academic knowledge comes directly from us, in a classroom, based on a written text, and assessed objectively. We must acknowledge our students as active, reflective, and resistant agents in their own educational process. We must come to terms with the reality that our particular expertise may have very little currency (or even relevance) in the messy and complex world outside our classroom walls. (Butin, 2010, pp. 19-20)

In the above text, I have only managed to touch on a small number of the issues that this particular service-learning experience raised-there were others that I plan to write on some other time. For example, students in the class challenged me about whether or not this service-learning placement (and, indeed, most service-learning) was not a form of poverty tourism, which may enhance student learning but comes at the expense of the communities concerned. While there is a fair-sized body of literature debating the benefits of service-learning for students, Cruz and Giles (2000) pointed out that there is rather less scholarly work looking at how communities experience it. The question of whether and how communities benefit from being part of service-learning initiatives is a very important but difficult one that deserves further research. If service-learning is really to contribute to struggles for social justice and thereby to positive social change, we need to be confident that service-learning placements, such as the one discussed here, really can meaningfully respond to community needs. This paper is limited to a reflection on the effects of the service-learning initiative on the students concerned. In further, still ongoing research I intend to explore the experiences of community partners in service-learning.

In terms of the focus of this paper-namely, the effects of the introduction of service-learning on student learning-the experience discussed in this paper suggests that service-learning experiences can encourage unexpected ways of learning. In the course described above, the service-learning component contributed to students' learning despite involving activities that were not obviously related to the academic content of the course. The time spent working alongside community members helped shape the class into a better learning community, which strengthened their ability to learn together, and was also helpful in getting them to better understand the on-the-ground dynamics of NGO work. This improved understanding of NGO dynamics will help those who plan to work in the NGO sector to be able to make a more meaningful contribution there and, more generally, may better equip students to contribute to positive social change.

In closing, my first experience of using service-learning taught me that introducing service-learning can be a fraught, difficult, and intense process, but that it can result in a range of very important kinds of learning. What is also clear is that it is service-learning's ability to lead us in unexpected directions that makes it valuable. Service-learning disturbs, it unsettles, it upsets. It is for precisely these reasons that it can make for a profoundly educational experience.

\section{Acknowledgements}

This paper could not have been written without the insights of students in the 2014 Poverty and Privilege class. I'm also grateful for advice from Mandy Hlengwa of the Centre for Higher Education Research, Teaching and Learning (CHERTL) at Rhodes University, and Sharli Paphitis from the Community Engagement Division at Rhodes University. Thanks are also due to CHERTL for allowing me to present an earlier version of this paper at the 2014 Teaching and Learning Showcase, and to participants at that event for their helpful suggestions. 


\section{References}

Artz, L. (2001). Critical ethnography for communication studies: Dialogue and social justice in servicelearning. Southern Communication Journal, 66(3), 239-250. http://dx.doi.org/10.1080/10417940109373202

Barry, B. (2005). Why social justice matters. Cambridge, UK: Polity.

Bender, C. G., Daniels, P., Lazarus, J., Naude, L., \& Sattar, K. (2006). Service-learning in the curriculum: A resource for higher education institutions. Pretoria, South Africa: Council on Higher Education.

Bringle, R. G., \& Hatcher, J. A. (1995). A service-learning curriculum for faculty. Michigan Journal of Service-Learning, 2, 112-122.

Butin, D. W. (2007). Justice-learning: Service-learning as justice-oriented education. Equity and Excellence in Education, 40, 177-183.

Butin, D. W. (2010). Service-learning in theory and practice: The future of community engagement in higher education. New York, USA: Palgrave Macmillan.

Cruz, N. I., \& Giles, D. E. (2000). Where's the community in service-learning? Michigan Journal of Community Service Learning, Special Issue, 28-34.

Eyler, J., \& Giles, D. E. (1999). Where's the learning in service-learning? San Francisco, USA: JosseyBass.

Howard, J. P. F. (1998). Academic service-learning: A counter-normative pedagogy. New Directions for Teaching and Learning, 73, 21-30.

Kezar, A. (2002). Assessing community service learning: Are we assessing the right outcomes? About Campus, 7(2), 14-21.

Lewis, T. L. (2004). Service learning for social change? Lessons from a liberal arts college. Teaching Sociology, 32(1), 94-108.

Mahlomaholo, S., \& Matobako, T. (2006). Service learning in South Africa held terminally captive by legacies of the past. Alternation, 13(1), 203-217.

Miller, D. (1999). Principles of social justice. Cambridge, USA: Harvard University Press.

Mitchell, T. D. (2007). Critical service-learning as social justice education: A case study of the Citizen Scholars Program. Equity \& Excellence in Education, 40(2), 37-41.

Osman, R., \& Petersen, N. (2013). Service learning in South Africa. Cape Town, South Africa: Oxford University Press.

Rhoads, R. A. (1997). Community service and higher learning: Explorations of the caring self. Albany, USA: State University of New York Press.

Rhodes University. (2016). What is service-learning? Retrieved from https://www.ru.ac.za/communityengagement/servicelearning/whatisservice-learning/

Scholz, S. J. (2000). Service-learning in ethics: A new pedagogical approach to the old theory-vs.practice challenge. In C. D. Lisman \& I. E. Harvey (Eds.), Beyond the tower: Concepts and models for service-learning in philosophy (pp. 185-192). Washington, USA: American Association of Higher Education.

Seider, S., \& Taylor, J. (2011). Broadening college student interest in philosophical education through community service learning. Teaching Philosophy, 34(3), 197-217.

South African Qualifications Authority. (2000). The national qualifications framework and curriculum development. Pretoria, South Africa. Retrieved from http://www.saqa.org.za 
Stanton, T. K., Giles, D. E., \& Cruz, N. I. (1999). Service-learning: A movement's pioneers reflect on its origins, practice, and future. San Francisco, USA: Jossey-Bass. 